\title{
Modes of disciplinary interaction as a line of escape in Family Health practice: a cartographic analysis
}

\author{
I ${ }^{1}$ Matheus Mendes Pereira, ${ }^{2}$ Mayara Karoline Silva Lacerda, \\ ${ }^{3}$ Cristina Andrade Sampaio, ${ }^{4}$ Patricia Helena Costa Mendes I
}

Abstract: The present study aims to discuss the knowledge and practices of Primary Health Care professionals about the modes of disciplinary interaction. It is a descriptive study, with qualitative approach following the methodological proposal of cartography, in which we ran four focus groups with the participation of 33 professionals, among them doctors, nurses and dental surgeons who are part of Family Health teams (FHt). With a cartographic mapping, it was possible to see that the work context of the FHt can be represented by the plan of form, which is affected by the plan of forces, generating interrelationships. From this, the modes of disciplinary interaction emerge as a line of escape, producing new assemblages characterized by the perspectives and proposals listed by the professionals. Through this mapping, the importance of the modes of disciplinary interaction in the FHt practice was evident, mainly as a response to the micropolitics of living labor in health with a focus on lightweight technologies.

> Keywords: Primary Health Care; Interdisciplinary communication; Cartography.

\author{
${ }^{1}$ Universidade Estadual de Montes \\ Claros. Montes Claros -MG, Brasil \\ (matheusmendesp@hotmail.com). \\ ORCID: 0000-0002-9794-298X \\ ${ }^{2}$ Universidade Estadual de Montes \\ Claros. Montes Claros -MG, Brasil \\ (mkslacerda@hotmail.com). \\ ORCID: 0000-0002-7188-227X \\ ${ }^{3}$ Universidade Estadual de Montes \\ Claros. Montes Claros -MG, Brasil \\ (cristina.sampaio@unimontes.br). \\ ORCID: 0000-0002-9067-4425 \\ ${ }^{4}$ Universidade Estadual de Montes \\ Claros. Montes Claros -MG, Brasil \\ (patyhcmendes@yahoo.com.br). \\ ORCID: 0000-0001-7150-8096
}

Recebido em: 06/09/2019

Aprovado em: 06/11/2019 Revisado em: 18/05/2021 


\section{Introduction}

Primary Health Care (PHC) constitutes the assistance level that represents the gateway for users to enter the service network. It is grounded by the principles of accessibility, longitudinality, comprehensiveness, coordination, and family and community guidance. It is the level of the health system that tends to the needs and demands of individuals, provides care aimed at the person, besides coordinating and integrating actions provided by other points in the network (STARFIELD, 2002).

In order to fulfill the functions of resolvability, accountability and organization, the Family Health Program (FHP), later called Family Health Strategy (FHS), was created to serve as a guide to the restructuring of the PHC in Brazil and, currently, it has consolidated itself as the main proposal for organizing this level of assistance. One of the main characteristics of the FHS is the formation of multiprofessional teams comprised of different categories, including physicians, nurses, nurse technicians and community health agents (CHA), with the possibility to include endemic combat agents (ECA), dental surgeon and dental assistant (BRASIL, 2017).

The main goal of the formation of multiprofessional teams is overcoming the fragmented view of health previously proposed by the hegemonic model, which proved to be inefficient in reaching better levels of health, seeing that no isolated professional is able to see to all demands of the population, making it necessary to assemble the multiprofessional team in order for them to perform a joint action. Such action brings forth benefits to the professionals, in the way of knowledge enrichment, and for patients, in the way of an integral assistance, which enables the solving of a multitude of health problems (MENDES, 2012; BORGES; SAMPAIO; GURGE, 2012).

In order to find an answer to this complexity, there arises the need to work on the modes of disciplinary interaction: multidisciplinarity, interdisciplinarity and transdisciplinarity in the health system practices within the scope of PHC. Multidisciplinarity is based on the definition of common goals shared by all members of the team, with no synthesis of functions, but the grouping of isolated methods and disciplines. Interdisciplinarity is achieved when this interaction happens in a way that favors cooperation among the professionals, which leads them to modify their initial knowledge through joint action and knowledge enrichment, culminating in the achievement of a common goal. In this context, there is an exchange of 
knowledge that goes beyond the limits of each individual field. From that, there arises transdisciplinarity, which is characterized by the removal of the limits that separate the specific knowledge of each profession, made possible by the strong interaction between the disciplines and the birth of a macro-discipline, which encompasses the joint action and the aggregation of knowledge with a more comprehensive focus (DOMINGUES, 2005; POMBO, 2005; SOMMERMAN, 2006; DIAS et al., 2015).

This joint effort presupposes the challenge of getting professionals out of their comfort zones and of acting only within the limits of the knowledge of their own professional class. There is a need to interact with the other professionals, going through the modes of disciplinary interaction, in which the main characteristic is the approximation of several disciplines aiming to solve specific problems (ROQUETE et al., 2012).

The lack of information on the professionals' part causes confusion and error as to the concepts of multidisciplinarity, interdisciplinarity and transdisciplinarity (ROQUETE et al., 2012). The predominant guidance in higher education is still limited and does not target the development of students' critical thinking, inserting it later on, with little to no contact with different professional categories. Modes of interaction are rarely explored by educational institutions, and that is reproduced in health teams. That results in each individual acting separately and in the overlapping of care actions and its fragmentation (SOUSA; BOGO; BASTOS, 2013; AASE; HANSEN; AASE, 2014).

Taking the complexity of PHC demands into account, the need for the joint work of the teams and the deficit in the education of professionals, we see the importance in evaluating the knowledge of teams working in the PHCabout the modes of disciplinary interaction: multidisciplinarity, interdisciplinarity and transdisciplinarity, in regards to the conceptual characteristics that distinguish those terms, as well as identifying and describing their experiences in regards to interprofessional relationship practices. Thus, this study aims to discuss the knowledge and practices of PHC professionals regarding the modes of disciplinary interaction.

\section{Methodological Path}

This is a descriptive, exploratory study, with a qualitative approach, with the methodological proposal of Cartography. The cartographic technique allows for 
the understanding of phenomena in the context in which they occur, valuing the relationship between the researcher and the phenomenon under study, allowing not only for the representation of objects, but also for the monitoring of processes (DELEUZE; GUATTARI, 1995; PASSOS; KASTRUP; ESCÓSSIA, 2015). Thus, reality is conceived as a mobile map in which, through the vibrant eye, the researcher perceives the production in the health field from its intensities and affects (MERHY, 2014). Cartographic research considers intervention as a fundamental characteristic, not separating the researching from the intervening, treating them as concomitant actions, making it necessary to intervene in order to know the process, not dissociating the role of the researcher and their intervention in the context (PASSOS; KASTRUP; ESCÓSSIA, 2015).

In this logic, we used this method aiming to map the perception and practices of the PHC professionals regarding the modes of disciplinary intervention, investigating the representation of this phenomenon within the social context in which the professionals operate. In order to interpret the everyday experiences and the way they were assimilated in their practice scenarios, it was necessary to emphasize subjectivity and singularization which, based on the propositions of Cartography, allow for a better understanding of the phenomenon under study (MINAYO, 2010; GUATTARI; ROLNIK, 2013).

We collected the data between April and October 2018 in 14 FHS teams, which were appointed by the city government as they were teams that had been working for longer in the same area and were comprised of the three minimum categories of higher education professionals: nurses, dental surgeons and physicians. It is, therefore, an intentional sample.

We used four focus groups to collect the data, each with six to 12 members and with an average duration of one hour, which were scheduled previously through an invitation letter asking them to contribute to the research. At this point, 33 professionals were participating on the study. The groups were conducted based on the following guiding questions: "What do you know about the modes of disciplinary interaction: multidisciplinarity, interdisciplinarity and transdisciplinarity? What are your experiences and perspectives on this subject?".

The focal groups were filmed and recorded. Their speeches were transcribed in order to be analyzed and interpreted, following the precepts of Cartography (PASSOS; 
KASTRUP; ESCÓSSIA, 2015). To guarantee anonymity, the interviewees were assigned successive alphanumeric codes starting at E1, meaning the sequence in which they manifested during data collection; associated to the focal group number; G1 to G4, in which the interviewee participated.

After the transcription of all groups, we carried out the discourse analysis. Through this analysis, it was possible to identify the interdiscourse, characterized as a pre-built or discursive memory, and the intradiscourse, defined as that which is said based on the current conditions (LIMA, 2003). This process of analysis happens through immediate transcription, repeated readings, determination of thematic axes and categories and deepening of the content within the specified categories (BOSI; MACEDO, 2014).

For the interpretation of the data, from the perspective of Cartography, the concepts of plan of form, plan and lines of forces, assemblages, lines of escape and rhizome were applied in order to build a dynamic, non-static map, representing a diversified environment, highlighting its subjective character, originated from the frequent affections (DELEUZE; GUATTARI, 1995; SOARES et al., 2018).

Plan of forms is the part of the mapped process that is formed by hard lines and composed of the instituted and binary aspects. In this sense, the plan of forces is associated with the part of the process that is composed of flexible and malleable lines that affect the form and shape it momentarily. This is because these affects of flexible lines on the plan of forms, called assemblages, occur dynamically and are constantly changing, starting with new successive assemblages. From them, there might arise the lines of escape, in the form of consequences of assemblages and characterized by active processes, which can be unpredictable, but which culminate in changes (ESCÓSSIA; TEDESCO, 2012).

The focus groups were carried out after the consent from the Municipal Health Department through the signing of the Consent Term of the Institution, and from the participants through the signing of the Free and Informed Consent Term. This is a research originated from a master's thesis, which was approved by the Research Ethics Committee under Opinion No. 2555,069 and followed the guidelines of Resolution No. 466/12 of the National Health Council (BRASIL, 2012) and does not present conflicts of interest. 


\section{Results and Discussion}

As to the characterization of the 33 research subjects, 10 were physicians, 14 were nurses and nine were dental surgeons. Out of the total, 30 (90.9\%) were female and the ages ranged from 25 to 63 , with a higher occurrence of participants aged between 30 and 39 (66.6\%). The time since graduation varied from one to 35 years, with 14 (42.4\%) participants having nine or more years since graduation. As for the length of experience of professionals in the FHS, there was a variation from seven months to 17 years, with 18 (54.5\%) of them having worked for less than five years. Regarding the subjects' titles, eight (24.2\%) had only an undergraduate degree, six (18.2\%) were specialists in the Lato sensu modality, 17 (51.5\%) had a specialization in the Family Medicine Residency modality and two (6.1\%) had a master's degree in health.

The analysis and understanding of the reality observed, as well as the cartographic monitoring of teams' performance processes, were only possible through the insertion and experience of the researcher in the daily work process of the Family Health teams (FHt). This is because mapping means following inventive processes and the production of subjectivity, due to the insertion in the daily life of the teams, which allows the cartographer to determine the design of the network of forces in which the phenomenon under study is being affected, contemplating the connections, mobility and permanent mutations made possible by immersing the cartographer in the collective fields of force (PASSOS; KASTRUP; ESCÓSSIA, 2015).

Allowed by this approach and facilitated by the transcription of the videos of the focus groups, the investigation culminated in the identification of three categories: "The insignificant conceptual confusion on the modes of disciplinary interaction"; "The lines of force and their effect on the plan of forms of the PHC" and "Perspectives and Proposals elaborated through the influence of micropolitics made possible by the cartographic method.

Before going any deeper in the categories identified, it is necessary to understand the complexity, the affections, the assemblages, as well as the compositions of the plans of form and force mapped by Cartography in regards to the work process at the FHt and, for that, we will approach them in the logic of progressive deepening, as a kind of zoom, in order to provide a holistic understanding of the object under study. 
Figure 1. Overview of the mapping produced by Cartography representing the modes of disciplinary interaction in the work process in Family Health Strategy

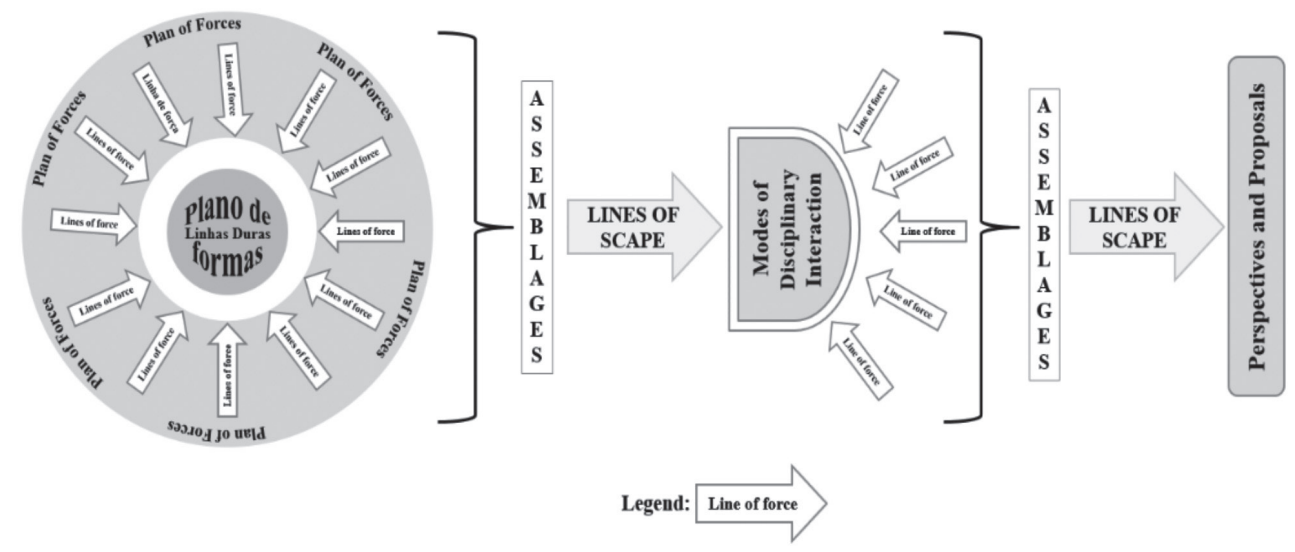

Source: Results of the study.

Initially, as represented in Figure 1, from a more comprehensive mapping of the cartographic plan, it is possible to see the existence of the shape or organization plan of the FHt, referring to the way reality presents itself. As far as it is concerned, the plan of forms is affected by the plan of forces, which makes it possible to affect subjectivity (ROMAGNOLI, 2009). This interrelationship between the plans characterizes the assemblage generated, from which the modes of disciplinary interaction as a line of escape emerge. Through the affectations of subjectivity caused by the flexible lines, there is the creation of zones of indeterminacy that allow new assemblages, which produce the appearance of other lines of escape, converging in processes that bring about the new (ROMAGNOLI, 2009). The modes of interaction, in turn, are affected by lines of force related to the subjective and methodological questions of this study, which trigger a new responsible assemblage process, now, due to the appearance of the consecutive line of escape, formed by the perspectives and proposals identified by the research subjects.

On the illustration, it is possible to see an essential characteristic of Cartography: the processes are always considered incomplete, guided by a rhizomatic logic, in which central stems generate junctions, which receive influences and affections that relocate them to central positions and from which new junctions emerge. This logic addressed by Deleuze and Guattari (1995) shows continuity, cyclicality and dynamics of the processes followed by Cartography. 
The plan of forms represents the work process of the FHt, being composed of hard lines: dead labor, objectivity, PHC demands and macropolitics. The plan of forces, on the other hand, is formed by lightweight technologies, micropolitics, PHC demands, subjectivity and living labor in healthcare. In this description, the double effect of PHC demands stands out, which constitutes a hard line, composing the plan of forms, as they are characterized by the expected and instituted complexity of the needs that arrive at PHC. Concomitantly, these demands are also presented as lines of force, composing the plan of forces, since they affect the form, precisely due to the flexibility and specific characteristics of the local reality. In this case, they are not instituted nor binary, but fluid and multifaceted (Figure 2).

Figure 2. Highlight of the cartographic plan showing the plan of forms being affected by the plan of forces. From this relationship sprout assemblages from which emerge the modes of disciplinary interaction as lines of escape in the performance of Family Health Strategy professionals

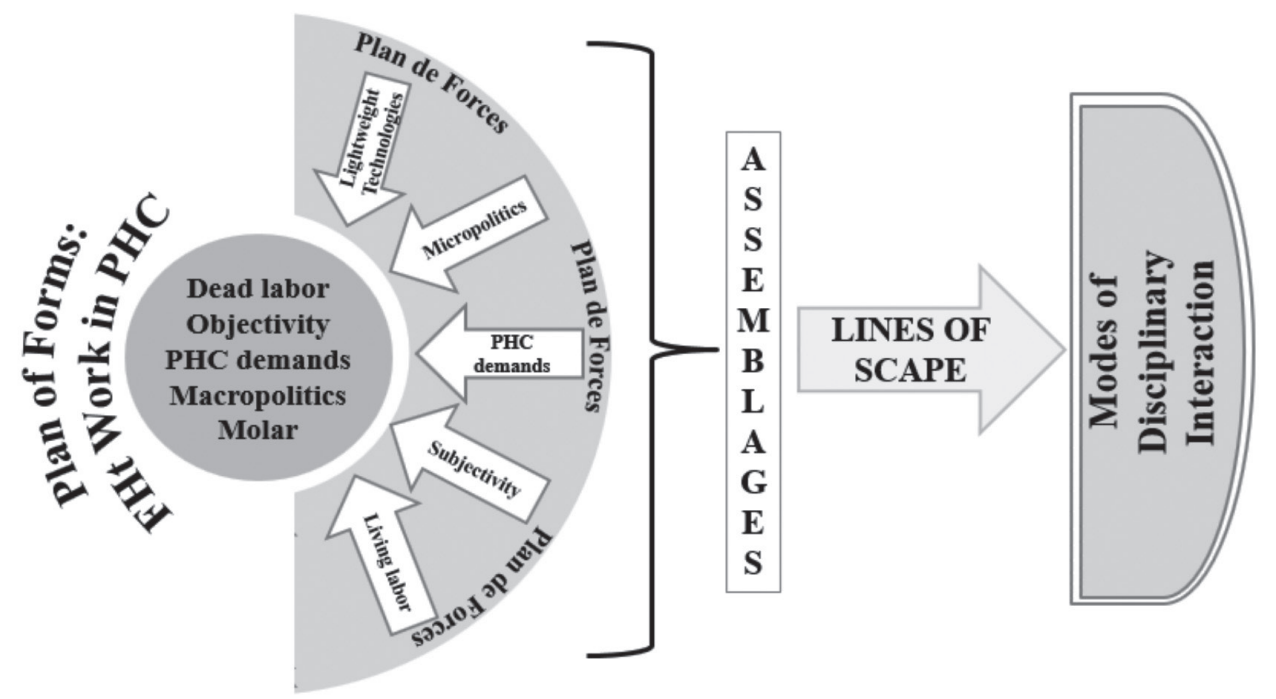

Source: Results of the study.

The reality mapped showed the coemergence between objectivity and subjectivity; instituted and instituter; macropolitics and micropolitics. The impositions, norms, guidelines and protocols that determine the functioning of the work process of the FHt are related to the instituted and the objective, that is, to what makes up the 
macropolitics. This, in turn, is affected by the practices encompassed in the field of micropolitics and local subjectivity, a field that, according to Merhy (2002), is characterized by the reactive and subjective attitudes of workers, by the health practices developed according to the social context, the actions of the community and the relationships established.

When analyzing the assemblages caused by the relationship between the instituted and the subjective of micropolitics, concepts and results also observed by Soares et al. (2018), we identified the appearance of the modes of disciplinary interaction in the form of lines of escape generated as tools for reaching the resolvability required for PHC. Through the professionals' characteristics and attitudes, the disciplinary interaction is consolidated as a way out of the assemblages generated from the relationship between the instituted demands and the micropolitics of the work process containing living labor and its technologies (Figure 2).

The valorization of lightweight and light-hard technologies is associated with obtaining better results, as these enable the valorization of micropolitics (MERHY, 2002), which confirms the reality mapped in the present study. In the micropolitics of the work process in healthcare, it is found to be open to living labor by means of the permanent creativity of the worker, who has the possibility to lead to the invention of new processes or even open them up in different and not thought of directions. In this micropolitics, the lightweight, light-hard and hard technologies allow for a productive restructuring of the healthcare sector, centralizing it on the territory of the lightweight technologies (MERHY, 2014).

Thus, as shown in figure 3, it was also possible to identify the capture of living labor through the determinants of dead labor, in the sense that the plan of forms is composed of hard technologies, such as norms, through the National Primary Health Care Policy (NPHCP), the productivity requirements and the often-precarious infrastructure; and by light-hard technologies: the instituted knowledge, such as clinic and epidemiology. Thus, through the impact of this plan by malleable lines linked to the lightweight technologies, attributes dependent only on the professionals, such as posture, attitudes, initiatives, autonomization and management of work processes, the disciplinary interactions emerge as a resolutive and problem-solving line of escape, with the common goal to solve specific and complex problems of patients (ROQUETE et al., 2012). 
Figure 3. Plan of forms characterized by dead labor, on which the plan of forces represented by living labor falls, generating the modes of disciplinary interaction as a line of escape
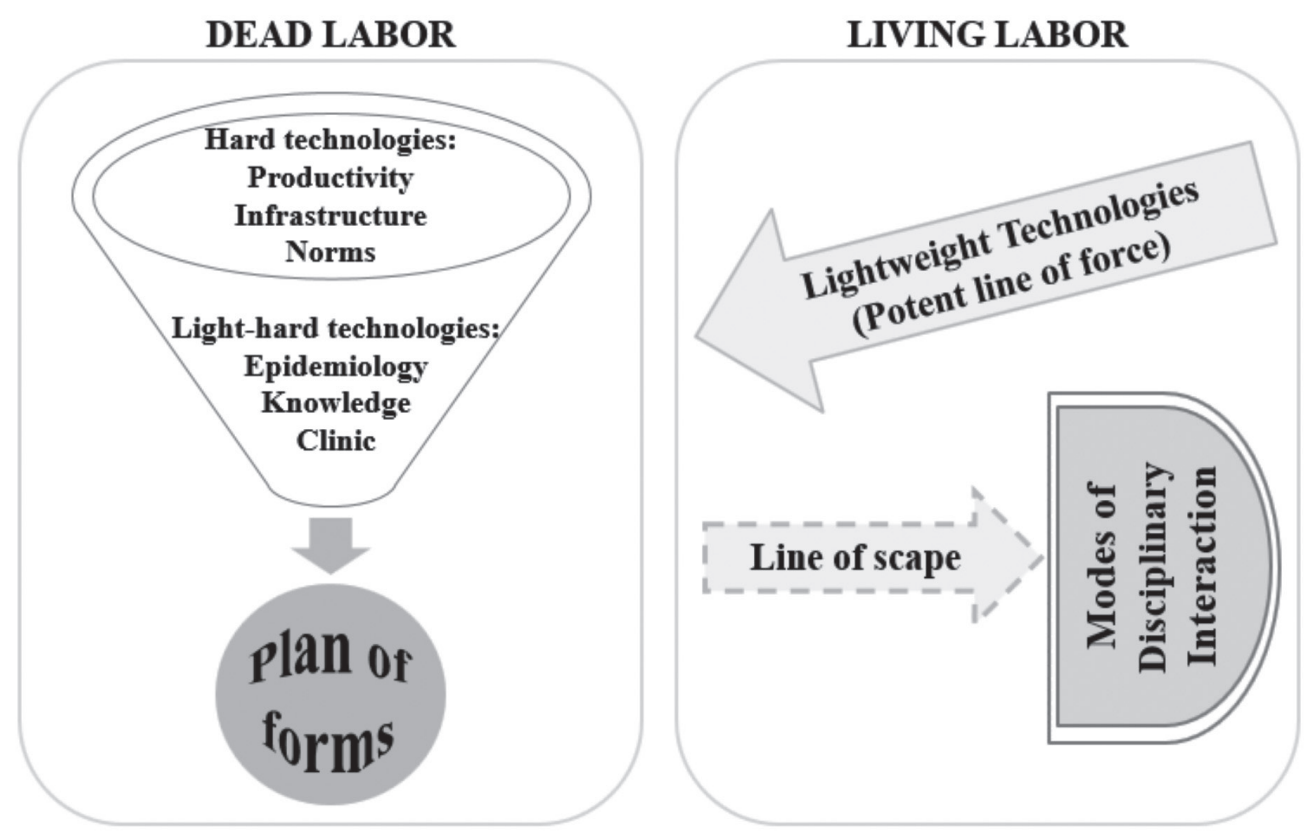

Source: Results of the study.

Merhy (2014) points out that, currently, work in healthcare is mostly institutionalized, based on collective work done by multiple health professionals or not. However, assistance is often fragmented due to an intermittent and compartmentalized approach, making it necessary to rethink the hegemonic care model in order to break the excessive fragmentation of care and to place the patients' needs as the focus of the professional performance. This new reality of the care model corroborates the importance of a performance guided by the modes of disciplinary interaction (ROQUETE et al., 2012).

After presenting the cartographic plan, we continue on to discuss the categories that emerged in the process of discourse analysis. 


\section{Category 1 - The insignificant conceptual confusion of the modes of disciplinary interaction}

During the execution of the focus groups, it was possible to see some difficulty on the part of the professionals in conceptualizing the terms that represent the modes of disciplinary interaction, specially transdisciplinarity.

G2E3: “Actually, I wasn't so sure about these concepts. Is interdisciplinarity more closely linked to transdisciplinarity or to multidisciplinarity? And is it [...] really a sharing of skills by the same professionals?"

G2E9: "Transdisciplinarity is harder to define. It seems to be very similar to interdisciplinarity, but there's a difference: it has to do with the limitations of the professionals' performance."

Dias et al. (2015) claim that transdisciplinarity eliminates the barriers that separate the specific knowledge of each profession, since it presents itself as an interaction that transcends the knowledge exchange, creating what is called a macrodiscipline, represented by the knowledge built from the contributions and sharing of experiences of all professionals.

Although there is a discussion in the literature about the modes of disciplinary interaction and their importance in the professional practices, we note that the theoretical basis is still lacking and that, at times, the terms and their definitions are used incorrectly, usually as synonyms to team work, which shows the need for a deeper discussion on the subject (ROQUETE et al., 2012).

This confusion in the conceptualization is linked to the lack of discussions and previous theoretical research on the subject, whether in academic education or in professional development.

G2E9: "I have seen and worked with several people who didn't have this academic knowledge. They didn't have the knowledge, but they had personal matters that made it easier. They couldn't conceptualize it, you see? They couldn't conceptualize it because that wasn't part of their academic studies...”

The current trend of specializations within the areas of expertise, often engaged in universities, makes the professionals more and more closed up in their own knowledge, making the approaches individualized (DIAS et al., 2015). Healthcare professionals tend to work independently and isolated from other professions as they follow their professional path based on their education and professional activity (PEDUZZI et al., 2013). In this sense, changes in healthcare professionals' education have become 
more relevant in the discussions of the pedagogical projects of the courses, with emphasis placed on the need to guide the training of these professionals to meet the needs of the Universal Healthcare System (SUS) (PARE et al., 2012).

It is important to highlight the FHS context, the demands and realities of the $\mathrm{FHt}$, as lines that affect form and encourage professionals to practice the modes of disciplinary interaction, even with the lack of theoretical knowledge on the subject. This impact shows the importance of an interactive practice among the members of the FHt, even when it is not following the theoretical input, which has rendered the conceptual confusion "insignificant", since it does not impede the application of the modes of disciplinary interaction by the teams.

G2E9: "At work we end up using this concept in practice, but we don't even know or realize it. It really is knowing by doing [...]. In a way, the FHP context demands a professional attitude that leads to that, and if you don't have it, you won't be able to handle working in FHP."

G2E5: "I believe that, no, that's a fact; these concepts are completely inserted in the program. [...] We might not stop to conceptualize them, but we're using them all the time..."

In the study carried out to assess the knowledge of professionals with higher education working in basic healthcare centers about this subject, we observed that the organization of services is fragmented, despite being composed of multiprofessional themes. The study pointed out that $93.7 \%$ of professionals referred to the existence of interdisciplinary actions, but showed insufficient knowledge about it, leaving the concept undefined or confusing. We concluded that, even with difficulties in distinguishing the concepts, the professionals recognize the importance of joint actions and the integration of knowledge (COSTA, 2007). This conceptual difficulty is also presented by Behrendt et al. (2019) in a study done in Germany.

Understanding the importance of these concepts, but specially of their practical implications, the professionals associated the modes of interactions as approaches that are intrinsic in PHC within the scope of Family Health, an attitude that makes the professionals stand out precisely for the resolutive, integral and integrated approach made possible by the modes of disciplinary interaction. Likewise, in a study by Ma and Saw (2018), the importance of disciplinary interaction was associated with obtaining comprehensive care and assistance.

G2E5: [...] we become differentiated professionals; we don't fully grasp the extent of the knowledge we acquire [...]. Multidisciplinarity alone isn't enough. If each of us only works in their own office, it becomes a private practice." 
During the group discussions, besides conceptualizing the modes of interaction, the professionals listed examples and experiences they had concerning the subject. From that point, it was possible to see that the FHt practices permeate the modes of interaction through multidisciplinarity, such as the care of a single patient by several professionals in an isolated way and interdisciplinarity, such as case discussions, reception, shared care, interconsultation, construction of Singular Therapeutic Projects (STP), matrix-based strategies and shared home visits; but with no reports that point to experiences based on transdisciplinarity.

G1E1: "Multidisciplinarity is when several professionals work separately, [...] but they don't have discussions. For example, we get a patient and each one does their own care, without having a proper group discussion. When it's interdisciplinary, we do one single consultation, either as a team, or we sit down to discuss [...]. Now, transdisciplinarity is something I don't really understand (laughs).

Among these evidences, the theoretical confusion of the terms reflected on their opinions, especially when it came to transdisciplinarity, where the activities experienced by the FHt were based on approaches linked to intersectoriality, that is, the interaction with sectors outside of healthcare, such as the religious, education, social assistance, safety and business sectors.

G3E5: "Trans goes beyond [...], it's when we look for support in areas that are not necessarily linked to healthcare, but that are also involved, isn't it?"

Iribarry (2003) and Roquete et al. (2012) define transdisciplinarity in a different way: it emerges as a working tool and presents itself as a challenge in the current scenario of health services, characterized by the removal of the limitations of each profession, given the immense integration between the workers, which culminates in a large aggregation of knowledge and practices, and the emergence of a macrodiscipline that encompasses all of the other ones involved in the situation.

When addressing the matter of the importance of the FHt action based on the modes of interaction, the professionals highlighted the positive effects of resolvability regarding the integrated care of the patient and the professional aggrandizement in the sense of knowledge aggregation and practices for the members involved.

G3E6: "Oh, my, I think that's everything! Because the greater the knowledge that you have of how your performance and that of the other professionals who are close to you should be like, the better the problem solving will be; the better it will be for the user looking for that service." 
A study done in Canada with PHC teams showed the professionals' satisfaction in acting together, sharing responsibilities and reducing the weight of the workload. The aforementioned study also discussed about the benefits of the team's collaborative action to the patients who received more holistic care, with a higher coordination and continuity, with less waiting time and having the chance to know the different professionals who compose the team, creating and strengthening the bond with them (MACNAUGHTON; CHREIM; BOURGEAULT, 2013).

\section{Category 2 - The lines of force and their effects on the PHC plan of forces}

During the discussions in the focal groups, several factors were listed as facilitators and complicators in the process of interaction among the FHt members. In the cartographic plan, these factors can add to the lines of forces already shown, which affect the plan of form and, because they are flexible and malleable, have positive, negative and double effects. In this context, it is possible to resort to Deleuze and Guattari's (1995) concept of virtual, applied to the lines of double effect, referring to the potential of entities and individuals to take on different identities depending on the lines that affect them. This immanence considers that, despite being in the same plan, the effects generated by the lines of force will be distinct, according to the affects generated, in this case, according to the positive, negative and double effects (Figure 4). 
Figure 4. Lines of force of positive, negative and double effect which affect the plan of forms

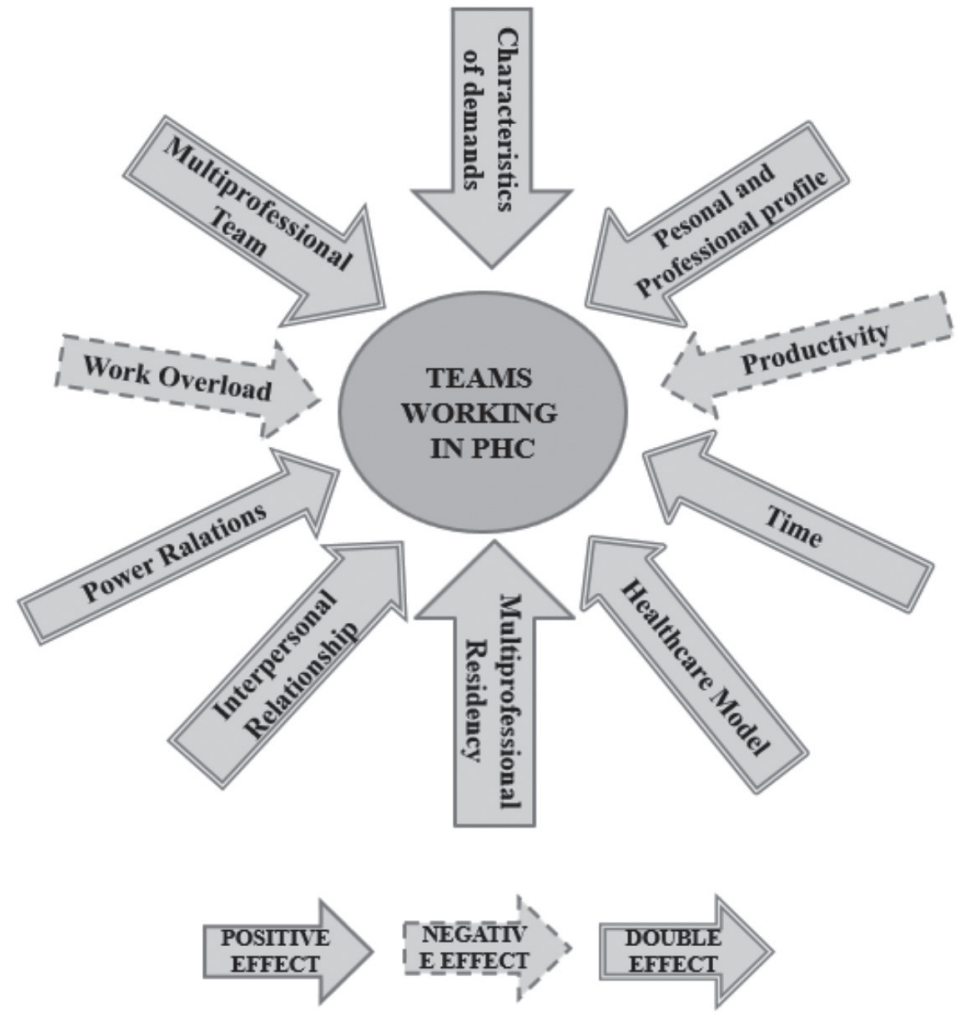

Source: Results of the study.

As lines of positive effects, we have the characteristics of demands, since, as previously discussed, the reality and complexity of the demands that arrive at the PHC interfere positively in the plan of form, boosting the escape of the modes of interaction as lines of escape; as well as the fact that the FHt is or was a residency center for family medicine, especially the multiprofessional one, which stimulates professionals to engaged in team work.

G3E4: I think that what really helped was that this place was a residency center, [...] working with interdisciplinarity is part of the residency routine"

As lines of negative effect, the demand for productivity stands out, occurring in a duplicated manner: on the part of the community, who demands more and more visits, consultations and procedures and do not understand the need 
and importance of the discussions among the professionals, and on the part of the management, who establishes targets linked to production, number of consultations and procedures, but does not include the need for team interaction in those targets.

G3E4: “There are two things, I think the pressure we're under, that we have to be productive and the community wants to receive care and have their problem solved, but to solve the problem, they often don't understand that we need to sit down and discuss, right? People want an answer to their problem, no matter how it happens."

Yet another line of negative effect is the overload of workers, characterized by the excess of clinical demands, the need to provide care to all life cycles and also administrative and bureaucratic ones, such as the management of the health center and the feeding of the information systems, which demand time and deadlines. Emphasis was placed on the work overload of nurses who perform the role of assistance and management, which makes professional interaction difficult, but not impossible. This work overload of FHt was also identified in a study by Soares et al. (2018) who associated it to the managers' demands, which limited more significant and higher quality actions in the scope of PHC.

G1E6: "So, it's our work overload that makes it hard to put that in practice. We want to do it, but the demand gets in the way."

The lines of force of double effect are shown in Table 1. They are characterized by showing both a positive and a negative impact. Some aspects stand out among the lines of double effect, such as the interpersonal relationship, which can vary between satisfactory and unsatisfactory relationship with the team, with fights being cited as negative effect; professional and personal profile: with respect, good communication, attitude and openness cited as positive effects, and shyness, traditional education, fear of showing weakness, insecurity, lack of communication and openness as negative effect.

G3E4: "I think that the professional who doesn't have the ability to have a good relationship with others has a complicating factor [...] It's a personal matter."

The quality of communication and the collaboration among the different professionals involved in the care are essential for the resolvability of services and the effectiveness of health care. 
Table 1. Lines of forces and their effect on the plan of forms

\begin{tabular}{lll}
\hline Line of force & Positive effect & Negative effect \\
\hline Interpersonal Relationship & $\begin{array}{l}\text { Good relationship } \\
\text { with the team }\end{array}$ & $\begin{array}{l}\text { Ineffective relationship with the team } \\
\text { Fights, Intrigue, closeness }\end{array}$ \\
\hline \multirow{2}{*}{$\begin{array}{l}\text { Personal and } \\
\text { Professional Profile }\end{array}$} & $\begin{array}{l}\text { Communication } \\
\text { Openness } \\
\text { Solicitude and Posture }\end{array}$ & $\begin{array}{l}\text { Insecurity } \\
\text { Lack of Openness } \\
\text { Shyness } \\
\text { Traditional training } \\
\text { Fear of showing weakness }\end{array}$ \\
\hline Multiprofessional Team & $\begin{array}{l}\text { Support } \\
\text { CHS }{ }^{* 1} \text { attitude }\end{array}$ & $\begin{array}{l}\text { Bad attitudes of CHA } \\
\text { High turnover of team members }\end{array}$ \\
\hline Pongitudinality & Horizontality & Verticality and hierarchy \\
\hline Time & Management of time for & Lack of time due to work overload \\
\hline Care Model & interaction & $\begin{array}{l}\text { Health Center and the presence of } \\
\text { specialists }\end{array}$ \\
\hline
\end{tabular}

${ }^{{ }_{1}}$ Community Health Agent

Source: Results of the study.

In assistance models based on team work in which the action involves several professionals, some barriers are pointed out, in special the difficulty to coordinate the roles of the professionals in order to create a cohesive set of services and, often, the lack of trust and respect among the members of the team (MACNAUGHTON; CHREIM; BOURGEAULT, 2013; BÉLANGER; RODRIGUEZ, 2008).

As for the multidisciplinary team line of force, the professional attitude of the $\mathrm{CHA}$ takes on a leading role and, when it focuses on facilitating the link between the users and other professionals of the team, it triggers an important positive effect, as well as longitudinality, characterized by the link between the professionals of a same team and with the community. As negative effect related to the multiprofessional team, we have the high turnover of professionals and the inadequate professional attitude of the CHA, seeing that they are opinion makers. Regarding power relations, they lead to positive effects when employed horizontally, and to negative effects when applied vertically and hierarchically. Time also has a double effect, 
since it can be used for the interaction among the team members, but the lack of it negatively impacts the difficulty of acting based on the modes of interaction.

G2E5: "The turnover of team members and the lack of longitudinality really get in the way."

In a study done in Canada with two multiprofessional PHC teams, it was possible to see that some factors were pointed out by the participants as elements that interfere with the interdisciplinary action, such as structural factors related to the physical space, workload, member turnover, team's hierarchy and composition; interpersonal factors related to education, trust, leadership and relevance of professional knowledge, as well as some personal traits (MACNAUGHTON; CHREIM; BOURGEAULT, 2013).

Finally, the care model based on the logic of the FHS has a positive effect on the interaction of the teams. Nevertheless, when there is no interaction among the professionals and they each work in isolation as it happens in a health center, and in the presence of specialists that confound the population in regards to the functions and autonomy of each member, the effects tend to be negative.

\section{Category 3 - Perspectives and proposals elaborated by the influence of micropolitics made possible by the cartographic approach}

As seen in the first cartographic representation, the modes of disciplinary interaction arise as a line of escape of the plan of forces over the plan of forms. From that, this line of escape is relocated to a central position and is influenced by new lines of force, in this case, the micropolitics represented by the professionals' actions and attitudes. With the assemblages caused by the lines of forces: micropolitics and cartographic approach, two new lines of escape appear in this rhizome: the perspectives and the proposals. Perspectives are points listed by the participants for changing reality, based on the conditions and local actions of the professionals themselves, while the proposals are presented as suggestions raised for the extrinsic application in the FHt (Figure 5). 
Figure 5. Perspectives and proposals as lines of escape produced by micropolitics and by the cartographic approach about the practices of the modes of disciplinary interaction in the Family Health Strategy

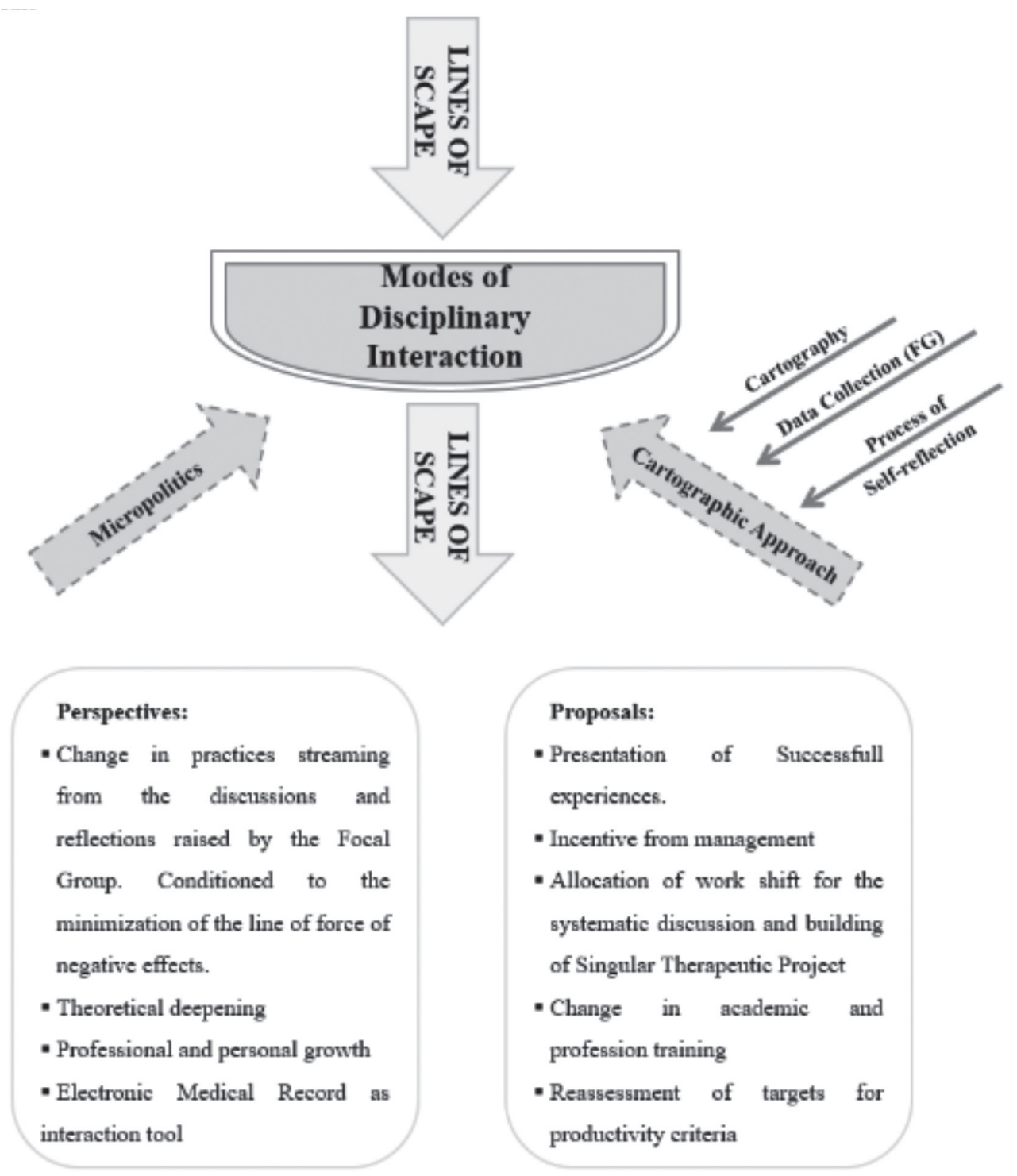

Source: Results of the study. 
This line of escape, generated by Cartography, is in accordance with the intrinsic intervention to the approach used, seeing that the rhizomatic reality monitored is not ecstatic and, thus, is subject to mutations and interventions. Cartography is based on the logic of methodological intervention, on the inseparability between the researcher and the subjects of the research, given the immersion of the cartographer in the study scenario and in the inseparability between research and intervention, considering them as simultaneous actions, being necessary to intervene in order to get to know the process (PASSOS; KASTRUP; ESCÓSSIA, 2012). These are the attributes that characterize the line of force of the cartographic approach, which also contemplates the affects caused by the data collection in the form of the focus groups' discussions, which triggered a process of self-reflection on the reality experienced, the themes and concepts discussed and the practices mentioned.

The cartographer acts directly on the subject to be mapped. The research is shaped by the strength of the meetings carried out, the folds created as the territories are treaded and inhabited. There is no asepsis, distancing or separation between research subject and researcher. The cartographer does not wish to remain neutral and distant. They do not collect data, but produce them. They do not judge; they call into question the forces that ask for judgment. They demand to be implicated in their own research movement as a primordial condition (COSTA, 2014; SAMUDIO et al., 2017).

Amongst the perspectives which have emerged from the process, we have: change in practice stemming from the discussions raised by the focal group and conditioned to the minimization of the lines of forces of negative effects; theoretical deepening to assist practice; behavioral changes with professional, personal and theoretical growth; use of the Electronic Medical Record (EMR) as a form of interaction among professionals.

G1E3: "I think that in spite of all the negative, we are going to have improvements, [...] I think we have to be open to these changes and adapt to them."

As for the proposals, the following were cited: a showcase promoted by the managers showing successful experiences, a meeting between the FHt to exchange ideas that can be replicated to assist other teams, for instance; incentive from management to teams that work in a more integrated logic; allocation of a work shift for the discussion and construction of a Singular Therapeutic Project (STP) by the local FHt; reformulation of the teams' production goals considering the 
need for specific time to discuss interdisciplinary work and change in the academic and professional training of FHt workers, so they can be more prepared for the performance based on the modes of disciplinary interaction.

G1E4: "I think that one important thing we should have is the sharing of experiences. [...] So, I think that the city government should promote more meetings among the professions and encourage participation."

Choi and Pak (2006) point out that among the factors that contribute to the success of the disciplinary practices are the incentives, where the main one must be the possibility and desire to respond to the demands; but also, the institutional support with incentives and rewards; besides the time to share experiences through communication among members, using feedbacks, compliments and constructive criticism.

\section{Final Remarks}

The present study showed the role of FHt in the scope of PHC which take on a rhizomatic character due to the variety of affects that continually shape them. The article mapped the reality of the FHt under the standpoint of the modes of disciplinary interaction, which emerge as lines of escape resulting from assemblages promoted by the affects of the lines of forces. This mapping revealed the importance of the modes of disciplinary interaction in the FHt practice as a response, especially, to the micropolitics of the living labor in healthcare, centralized in lightweight technologies

We identified that, in spite of the professionals' confusion when conceptualizing the terms multidisciplinarity, interdisciplinarity and transdisciplinarity, the teams' performance is based on these attributes, except for transdisciplinarity, which was referred to by the subjects as intersectoriality. That emphasizes the need to qualify professionals regarding the theoretical understanding of the proposal of disciplinary interaction, sensitizing them, in the professional and academic training sphere, about the relevance of these practices in health work in order to achieve better sanitary results both in the personal and collective levels.

Finally, we highlight the importance of focal groups as a method for data collection, due to the potential to promote collective discussions, which facilitates reflection on the subject under study, an indispensable element to allow changes and guide new processes. It is also worth mentioning the coherence regarding the use of Cartography 
as a reference for investigation, since it made possible to identify new perspectives and proposals through the professionals' perceptions. All in all, the professionals corroborated the notion that the disciplinary interaction is of paramount importance for achieving a higher level of resolvability in basic health services and highlighted that some important strategies to consolidate it are: the creation of a showcase of successful experiences to promote knowledge exchange among the professionals, and also the adjustment of productivity targets which would allow for moments of interdisciplinarity, in addition to other incentives on the part of management.

\section{References}

AASE, I.; HANSEN, B. S.; AASE, K. Norwegian nursing and medical students perception of interprofessional teamwork: a qualitative study. BMC Medical Education,v. 14, n. 1, p. 170, 2014.

BEHRENDT, C. A.; KÖLBEL, T.; SCHWANEBERG, T.; DIENER, H.; HOHNHOLD, R.; DEBUS, E. S.; RIEß, H. C. Multidisciplinary team decision is rare and decreasing in percutaneous vascular interventions despite positive impact on in-hospital outcomes. Vasa, v. 48, n. 3, p. 262-269, 2019.

BÉLANGER, E.; RODRIGUEZ, C.: More than the sum of its parts? A qualitative research synthesis on multi-disciplinary primary care teams. J Interprof Care, v. 22, n. 6, p. 587-597, 2008.

BORGES, M. J. L.; SAMPAIO, A. S.; GURGEL, I. G. D. Trabalho em equipe e interdisciplinaridade: desafios para a efetivação da integralidade na assistência ambulatorial às pessoas vivendo com HIV/Aids em Pernambuco. Ciência \& Saúde Coletiva, v. 17, n. 1, p.147-156, 2012.

BOSI, M. L. M.; MACEDO, M. A. Anotaçôes sobre a análise crítica de discurso em pesquisas qualitativas no campo da saúde. Revista Brasileira Saúde Materna e Infantil, v. 14, n. 4, p. 423432, 2014.

BRASIL. Ministério da Justiça. Resolução n. 466, de 12 de dezembro de 2012. Establishes regulatory guidelines for research involving human beings. Diário Oficial da República Federativa do Brasil, Brasília, 2012.

BRASIL. Ministério da Saúde. Portaria n. 2.436, de 21 de setembro de 2017. Approves the Policy on Primary Health Care, establishing the revision of guidelines for the organization of Primary Care in the scope of the Universal Health System (SUS). Diário Oficial da República Federativa do Brasil, Brasília, 2017.

CHOI, B. C. K.; PAK, A. W. P.; Multidisciplinarity, interdisciplinarity and transdisciplinarity in health research, services, education and policy: 1 . Definitions, objectives, and evidence of effectiveness. Clinical and Investigative Medicine, v. 29, n. 6, p. 351-364, 2006. 
COSTA, L. B. D. Cartografia: uma outra forma de pesquisar. Revista Digital do LAV, v. 7, n. 2, p. 66-77, 2014.

COSTA, R. P. Interdisciplinaridade e equipes de saúde: concepçôes. Mental, v. 5, n. 8, p. 107124, 2007.

DELEUZE, G.; GUATTARI, F. Mil platôs: capitalismo e esquizofrenia. 34. ed. Rio de Janeiro: Coleção TRANS, 1995.

DIAS, J. N.; LIMA, N. R. B; ARRUDA, N. C. L.; PINTO, J. B. A.; SILVA, M. P. C. F.; DIAS, V. N.; LIMA, I. P. C. INTER E TRANSDISCIPLINARIDADE NAS CIÊNCIAS: Consideraçóes disciplinares no campo da saúde coletiva. Revista da Universidade Vale do Rio Verde, v. 13, n. 2, p. 438-449, 2015.

DOMINGUES, I. Em busca do método. In: DOMINGUES, I. (Org.). Conhecimento e transdisciplinaridade II: aspectos metodológicos. Belo Horizonte: Editora UFMG, 2005.

ESCÓSSIA, L.; TEDESCO, S. O coletivo de forças como plano de experiência cartográfica. In: PASSOS, E.; KASTRUP, V.; ESCÓSSIA, L. Pistas do método da cartografia: pesquisaintervenção e produção de subjetividade. Porto Alegre: Sulina, 2012. p. 92-108.

GUATTARI, F.; ROLNIK, S. Micropolitica: cartografias do desejo. 12. ed. Petrópolis: Editora Vozes, 2013.

IRIBARRY, I. S. Aproximaçóes sobre a transdisciplinaridade: algumas linhas históricas, fundamentos e princípios aplicados ao trabalho em equipe. Psicologia Reflexão e Crítica, v. 16, n. 3, p. 483-490, 2003.

LIMA, M. E. A. T. Análise do discurso e/ou análise de conteúdo. Psicologia em Revista, v. 9, n. 13, p. 76-88, 2003.

MA, K. P. K.; SAW, A. A Qualitative Study on Primary Care Integration into an Asian Immigrant-specific Behavioural Health Setting in the United States. International Journal of Integrated Care, v. 18, n. 3, p. 1-11, 2018

MACNAUGHTON, K.; CHREIM, S.; BOURGEAULT, I. L. Role construction and boundaries in interprofessional primary health care teams: a qualitative study. BMC Health Services Research., v. 13, p. 486, 2013.

MENDES, E. V. O cuidado das condiçóes crônicas na atenção primária à saúde: o imperativo da consolidação da estratégia da saúde da família. Brasília: Organização Pan-Americana da Saúde, 2012.

MERHY, E. E. Saúde: a cartografia do trabalho vivo. 4. ed. São Paulo: Hucitec, 2014.

MERHY, E. E.; ONOCKO, R. Agir em saúde: um desafio para o público. 11. ed. São Paulo: Hucitec, 2002. 
MINAYO, M. C. S. O desafio do conhecimento: pesquisa qualitativa em saúde. 11. ed. São Paulo: Hucitec, 2010.

PARE, L.; MAZIADE, J.; PELLETIER, F.; HOULE, N.; ILOKO-FUNDI, M. Training in interprofessional collaboration: pedagogic innovation in family medicine units. Canadian Family Physician, v. 58, n. 4, p. 203-209, 2012.

PASSOS, E.; KASTRUP, V.; ESCÓSSIA, L. Pistas do método da cartografia: pesquisaintervenção e produção de subjetividade. Porto Alegre: Sulina, 2015.

PEDUZZI, M.; NORMAN, I. J.; GERMANI, A. C. C. G.; SILVA, J. A. M.; SOUZA, G. C. Interprofessional education: training for healthcare professionals for teamwork focusing on users. Revista da Escola de Enfermagem da USP, v. 47, n. 4, p. 977-983, 2013.

POMBO, O. Epistemologia da interdisciplinaridade. In: PIMENTA, C. (Coord) Interdisciplinaridade, humanismo, universidade. Porto: Campo das Letras, 2005.

ROMAGNOLI, R. C. A cartografia e a relação pesquisa e vida. Psicologia \& Sociedade, v. 21, n. 2, p. 166-173, 2009.

ROQUETE, F. F.; AMORIM, M. M. A.; BARBOSA, S. P.; SOUZA, D. C. M.; CARVALHO, D. V. Multidisciplinaridade, Interdisciplinaridade e Transdisciplinaridade: em busca de diálogo entre saberes no campo da saúde coletiva. Revista de Enfermagem do Centro Oeste Mineiro, v. 2, n. 3, p. 463-474, 2012.

SAMUDIO, J. L. P.; MARTINS, A. C. F. D. D.; BRANT, L. C.; SAMPAIO, C.A. Cartografia do cuidado em saúde mental no encontro entre agente comunitário de saúde e usuário. Physis, v. 27, n. 2, p. 277-295, 2017.

SOARES, I. C.; CUNHA, E. A. F.; VIERA JUNIOR, P. R.; VIEIRA, M. A.; LEITE, M. T. S.; SAMPAIO, C. A. Pela Mão de Sísifo: a sobrecarga do trabalho em equipes de saúde da família. Temas em Saúde, v. 18, n. 2, p. 2447-2131, 2018.

SOMMERMAN, A. Inter ou transdisciplinaridade: da fragmentação disciplinar ao novo diálogo entre os saberes. São Paulo: Paulus, 2006.

SOUSA, I. F.; BOGO, D.; BASTOS, P. R. H. O. Formação interdisciplinar para atuação no sistema único de saúde: síntese de artigos publicados no Brasil. Revista Saúde.com UFMT., v. 9, n. 2, p. 49-59, 2013.

STARFIELD, B. Atenção Primária: equilíbrio entre necessidades de saúde, serviços e tecnologia. Brasília: UNESCO, Ministério da Saúde, 2002.

ZWAREBSTEIN, M.; GOLDMAN, J.; REEVES, S. Interprofessional collaboration: effects of practice-based interventions on professional practice and healthcare outcomes. Cochrane Database Syst Rev., v. 3, n. 3, p. 72, 2009. 


\section{Resumo}

\section{Modos de interaçáo disciplinar como linha} de escape no trabalho em Saúde da Familia: uma análise cartográfica

O presente estudo objetiva discutir o conhecimento e as práticas dos profissionais da Atenção Primária à Saúde sobre os modos de interação disciplinar. Tratase de um estudo descritivo, de abordagem qualitativa, com a proposta metodológica da Cartografia, em que foram realizados quatro grupos focais com a participação de 33 profissionais, dentre eles médicos, enfermeiros e cirurgióes-dentistas, de equipes de Saúde da Família (eSF). A partir de um mapeamento cartográfico, foi possível perceber que o contexto do trabalho das eSF pode ser representado pelo plano de forma, que é afetado pelo plano de forças, gerando inter-relaçóes. A partir destas, emergem os modos de interação disciplinar como linha de escape, produzindo novos agenciamentos, caracterizados pelas perspectivas e proposiçóes elencadas pelos profissionais. Por meio desse mapeamento, ficou evidente a importância dos modos de interação disciplinar na prática das eSF como resposta, principalmente, à micropolítica do trabalho vivo em saúde, com centralidade nas tecnologias leves.

Palavras-chave: Atenção Primária à Saúde; Comunicação interdisciplinar; Cartografia. 